DOI 10.7764/ijanr.v48i3.2324

\title{
ESSAY \\ Innovative Rural Entrepreneurship in Chile
}

\author{
Félix Modrego ${ }^{1}$, and William Foster ${ }^{2}$ \\ 'Universidad de O'Higgins, Instituto de Ciencias Sociales. Rancagua, Chile. \\ ${ }^{2}$ Pontificia Universidad Católica de Chile, Facultad de Agronomía e Ingeniería Foresta, Departamento de \\ Economía Agraria. Santiago, Chile.
}

\begin{abstract}
F. Modrego, and W. Foster. 2021. Innovative Rural Entrepreneurship in Chile. Int. J. Agric. Nat. Resour. 149-170. Successful policies seeking to promote rural entrepreneurship require a conceptual model consistent with the features of rural spaces and free of stereotypes of entrepreneurship as being only technologically sophisticated. The objective of this essay is, first, to argue that rural areas can be fertile ground for entrepreneurial activities in middleincome countries such as Chile and, second, to discuss policy options to achieve the goal of encouraging a more innovative entrepreneurship in rural areas. The scientific literature on entrepreneurship and the definitions, types and roles of entrepreneurship in development are reviewed. The literature on the location of entrepreneurship is summarized to understand the drivers of observed territorial differences in entrepreneurial activity. One conclusion is that rural areas face a (seemingly) adverse economic geography for entrepreneurship, although there is a recent tendency for amenities-led growth. We then present the geography of rural entrepreneurship in Chile. Contrary to conventional wisdom, the rates of entrepreneurship in Chilean rural areas are high, although presumably of a limited growth potential under current conditions. Nevertheless, this entrepreneurial base provides a stock of knowledge from which a greater sophistication could be reached, and we discuss potential policy approaches to stimulate more innovative rural entrepreneurship. In the case of Chile, available policy options are coherent with the recently enacted National Rural Development Policy. A systemic, amenitybased approach gives middle-income countries opportunities for the development of more innovative rural entrepreneurship through territorial policies that provide local public goods and improve living conditions.
\end{abstract}

Keywords: Economic geography, entrepreneurship, rural development policy, territorial development.

\section{Introduction}

International evidence demonstrates that entrepreneurship, especially when it is growth-oriented, contributes to increases in productivity, to the

Received Mar 09, 2021. Accepted Nov 08, 2021

Corresponding author: fmodrego@gmail.com; wfoster@uc.cl generation of jobs and income, and, to innovation more generally (OECD, 2004). One would expect, therefore, that entrepreneurship would have the potential to be a driver of growth and development in rural areas. Nevertheless, the frequency and nature of entrepreneurial activities depend heavily on the local context in which they develop. 
The research in different countries shows sharp differences in entrepreneurial activity between subnational regions (Parker, 2009), with some areas showing a high and persistent entrepreneurial dynamism while others show chronic lag. This is also the case in Chile (Oyarzo et al., 2020). The relevance of local conditions has motivated a new generation of policies to promote entrepreneurship by building enabling environments and easing the emergence of entrepreneurial ecosystems (Isenberg, 2010; Mason \& Brown, 2014).

Can rural areas be a fertile ground for more innovative entrepreneurship in middle-income countries such as Chile? The first objective of this essay is to argue that this is the case, but achieving this goal requires a realistic view of entrepreneurship, detached from dominant stereotypes of entrepreneurial ventures as highly sophisticated businesses; rather it should be understood in a way that is more coherent with the real features of rural places. The second objective is to discuss how public policies can help in this task. Some general principles, such as adopting a systemic approach with respect to policy formation and coordination and making use of a coherent model of territorial policy, could assist in designing specific tools that accelerate a transformation of rural entrepreneurship. State institutions linked to the agricultural sector, such as the Ministry of Agriculture and related agencies, could play a role in coordinating government efforts in the entrepreneurship-support system. Government measures could promote more innovative rural entrepreneurship if they were to broaden their scope of action beyond the food chain and beyond the primary production and artisanal activities of the farm household.

To have a basis on which to assess the current state of rural entrepreneurship and possible policy directions, this essay first turns to a review of relevant definitions of entrepreneurship and the roles it might play in development. Entrepreneurship is a complex and heterogeneous phenomenon, and different types of entrepreneurship can contribute to different development objectives. We then briefly outline the economic literature on the location of entrepreneurship, which provides key insights for understanding the territorial differences in the entrepreneurial activity observed in the real world. One conclusion is that rural areas face a (seemingly) adverse economic geography for the development of more innovative entrepreneurship. There is a recent tendency, however, of rural economic growth linked to natural amenities, which both draw in business ventures and attract human capital. The adoption of a systemic, amenity-based approach opens the possibility, in middle-income countries such as Chile and others in Latin America, for the development of innovative rural entrepreneurship through territorial policies that increase local amenities and provide public goods that improve living conditions in the rural world.

We then turn to a brief characterization of the geography of entrepreneurship in Chile and the placement of rural areas in this geography. We show that, contrary to conventional wisdom, entrepreneurial activity rates in Chilean rural areas are high, but there are good reasons to suspect that in most cases, this entrepreneurship still has low innovation potential. Even so, we show that rurality is not a burden per se for new businesses to thrive. Rural areas cannot exploit the advantages of agglomeration economies and usually lack infrastructure, business support services and advanced human capital, which sorts into denser locations. Nevertheless, lower competition and lower business costs seem to be key locational advantages for endeavors that are mostly not reliant on complex, technical knowledge. At the same time, self-employment rates are high in rural areas, and this entrepreneurial base constitutes a stock of practical knowledge and skills that could be strengthened to reach a greater level of sophistication if enabling policies were implemented to activate this potential. Despite a broad portfolio of public support instruments for entrepreneurship, to date, rural entrepreneurs in Chile face a fragmented institutional setting, with agencies of 
the Ministry of Economy (CORFO, SERCOTEC) having limited embeddedness in rural places and agencies of the Ministry of Agriculture (mostly INDAP) supporting a narrow scope of endeavors beyond farm production (mostly agritourism and artisan food processing). Based on this argument, we provide guidelines for promotion policies so that decision-makers, such as the Ministry of Agriculture and its agencies, can help stimulate more innovative rural entrepreneurship. In the case of Chile, the available options are in alignment with the recently enacted National Policy of Rural Development.

\section{Entrepreneurship: what is it and what roles does it play in development?}

Entrepreneurship is generally associated with the creation of a new business, which, according to Malecki (2018), is described as the entrepreneurial event. However, as an ongoing economic and social phenomenon, entrepreneurship is much more complex and difficult to conceptualize. There are numerous definitions in the literature, each emphasizing different aspects of what is essentially a multidimensional phenomenon. Carree and Thurik (2003), for example, emphasize three main features of the entrepreneur. The first, based on the ideas of Joseph Schumpeter (1934; 1942), emphasizes entrepreneurship as the capacity to innovate. The second feature is influenced by the theories of Frank Knight (1921) and describes entrepreneurship as the capacity to take risks. The third feature, which was proposed by Israel Kirzner (1979), defines entrepreneurship as the capacity to be alert to market opportunities. Attempts to synthesize these views have led to more comprehensive definitions (e.g., Hébert and Lynk, 1989). One of the most quoted is that of Wennekers and Thurik (1999, page 46) who describe entrepreneurship as "the process of starting a business; using a manifest ability and willingness of individuals, on their own, in teams, within and outside existing organizations, to perceive and create new economic opportunities (new products, new production methods, new organizational schemes, and new product-market combinations) and to introduce their ideas in the market, in the face of uncertainty and other obstacles, by making decisions on location, form, and the use of resources and institutions."

From this perspective, entrepreneurship is fundamentally understood as a role of coordinating resources for the creation of economic value (Carree and Thurik, 2003). This role can be performed along several dimensions and is not limited to the creation of explosive-growth firms, technologically advanced businesses, or radical innovations in the popular, conventional sense. However, as emphasized by Welter et al. (2016), Kuratko and Audretsch (2021), and others, this high-tech bias still tends to dominate the entrepreneurship policy debate. In contrast, today scholars now seek to go beyond this perception bias to address entrepreneurship in its diversity of motivations, objectives and contributions to development. This broader perspective is particularly relevant to the analysis of the links between entrepreneurship and rural development because it brings more realism to the expectations of decision-makers regarding the type of entrepreneurship that can be nurtured in rural areas in less-developed countries.

Consequently, the ongoing entrepreneurship research agenda has endeavored to develop useful taxonomies for the characterization and study of entrepreneurship and the design of support policies rather than trying to reach a consensus regarding a universal definition. For example, influential international projects, such as the "Global Entrepreneurship Monitor" (GEM) or the "Regional Entrepreneurship and Development Index" (REDI), define the type of entrepreneurship according to entrepreneurs' motivations, distinguishing between entrepreneurship by necessity and entrepreneurship by opportunity (Reynolds et al., 2005; Szerb et al., 2013). The first term refers to entrepreneurship in basic, routine activities and is mostly motivated by a lack of alternatives in the labor market. The second refers 
to entrepreneurial activities linked to novel "value propositions" and attempts to exploit arbitrage opportunities. Similarly, Schoar (2009) differentiates between subsistence and transformational entrepreneurship. Another key distinction arises according to entrepreneurs' level of aspiration. Isenberg (2010), for instance, refers to aspirational entrepreneurship as having the ambition to scale up, which Mason and Brown (2014) similarly describe as growth-oriented entrepreneurship. Other distinctions are based on an ex post observation of the different types of companies that entrepreneurs create. In a highly influential study, Birch (1981) described entrepreneurial firms as "gazelles" (companies that are born small but that grow rapidly), "elephants" (born large with little growth) and "mice" (born small with little growth). Later, "unicorn" firms were added. This term refers to start-ups that are valued at US\$ 1000 million or more, explosive-growth endeavors that are typically found in technology-related sectors (Li et al., 2016). As noted by Welter et al. (2016), however, the bulk of entrepreneurship observed in reality, everyday entrepreneurship, does not adjust to the stereotypes of rapid-growth businesses in knowledge-intensive sectors.

The roles played by entrepreneurship in economic development are also heterogeneous. Traditionally, entrepreneurship has been thought to be a tool for employment creation, a catalyst of innovation, and a driver of productivity gains. Since the 1980s, with the work of Birch (1981), the view that entrepreneurship has disproportionate participation in employment creation has been widely accepted among policy-makers. Some authors question this view, however, stating that, just as new firms create many jobs, the high mortality rates of early-stage businesses imply that many jobs are also destroyed. In fact, new business mortality is so high that some studies describe the first three years of the firm as "the valley of death” (e.g., Kerr \& Nanda, 2009). As a consequence, the effect of entrepreneurship on net job creation will be low (Shane, 2009). Nevertheless, longitudinal studies have demon- strated that, having survived the first years, new businesses usually show a remarkable growth capacity and therefore have a large impact on employment (Haltiwanger et al., 2012).

The second role usually conferred to entrepreneurship is that of being a catalyst of innovation. There are various mechanisms that explain this relation. First, entrepreneurs can directly generate innovation, which is then usually commercialized through the creation of new businesses. In an empirical review of studies in different national contexts, Van Praag and Versloot (2007) conclude that entrepreneurial firms (new businesses that are typically small and aim to enter new markets) are particularly effective relative to their size in the generation and commercialization of radical and high-quality innovations. A second mechanism by which entrepreneurship facilitates the spread of innovation is by being a vector of new business ideas, management models and modes of production and commercialization. Even without generating innovation in a conventional sense (e.g., patents), new businesses are a manifestation of entrepreneurs' capacity to recombine resources in new (and possibly more efficient) ways (Carree \& Thurik, 2003). Others note that entrepreneurship is a process through which market forces can filter or sort potentially more productive and innovative projects from the stock of existing resources and ideas in local economies (Audretsch \& Keilbach, 2004). Similarly, entrepreneurship is a key element in the division of labor, acting as an intermediary or connector between the sources of basic (scientific) knowledge (such as universities and research centers) and the demands of potential downstream users as expressed through markets (Braunerhjelmet al., 2004). Entrepreneurs can act as specialized information aggregators and analysts of consumer/user demands, targeting the means by which innovations can be monetized more effectively than upstream scientists and engineers who specialize in more basic research. It is a separate skill to find commercial applications of scientific and technological developments. This bridging mechanism warrants policies 
to link academia, entrepreneurs and industry throughout the world.

The third role traditionally conferred to entrepreneurship is that of a productivity accelerator. The entry of new businesses to the market induces competition, which can stimulate a competitive response on the part of incumbent businesses (already in the market) to maintain their competitive position (Caves et al., 1992). The argument related to the notion of $x$-inefficiency (Leibenstein, 1966) is that greater competition induces business owners and managers to make organizational adjustments to create incentives for improved management and employee performance, spurring efforts to reduce organizational slack (Nickell, 1996). In addition, competition may stimulate systematic efforts in research, development and innovation (Geroski, 1990) and thus boost the productivity of enterprises, industries and regions. Evidence in various developed countries, such as Germany, the Netherlands and Spain, demonstrates how the industrial dynamic driven by the entry of new entrepreneurship is linked to improvements in the aggregated productivity of regional industries and economies (Brixy, 2014; Bosma et al., 2011; Callejón \& Segarra, 1999). The role of firm entry in boosting productivity has been demonstrated even for the sector of the smallest firms in Chile (Modrego \& Foster, 2021).

Despite the links between entrepreneurship and employment generation, innovation, and business productivity, it is not clear whether greater rates of entrepreneurial activity are significantly linked to higher levels of economic growth and development. In contrast, as Figure 1 suggests, one might conclude the opposite: countries with lower GDP per capita tend to have greater rates of entrepreneurship (TEA in the figure). This correlation is partly explained by the characteristics of entrepreneurship that predominate at different levels of economic development. In poorer countries (and regions within countries), there are usually greater levels of entrepreneurship; however, such entrepreneurship mainly takes the form of self-employment with doubtful growth potential. Once these differences are controlled, entrepreneurship by opportunity or growth orientation is positively and significantly related to improved aggregate economic results, as shown by Wennekers et al. (2005) at the country level and by Stephens et al. (2013) for counties in the United States.

Finally, it is worth noting other roles of entrepreneurship in development identified in the literature. Entrepreneurship can provide economic alternatives to households and individuals with low levels of qualification that limit their access to formal, stable and well-paid jobs (Naudé, 2010). Tamvada (2010) conducted a study in India that showed how self-employment allows workers with low school attainment to obtain greater incomes than those in informal or temporary employment, thereby providing vulnerable households a way out of poverty. Entrepreneurship is also a powerful mechanism that buffers the unemployment effects of negative shocks to the economy. This buffering role of entrepreneurship has inspired diverse programs around the world, for example, tackling unemployment among young people following the 2008 financial crisis in Europe (European Council, 2013). Consequently, entrepreneurship can also play an important role in regional resilience against diverse shocks. Entrepreneurship contributes to productive diversity and to building the capacity for regional adaptation to changing economic and social environments (Williams and Vorley, 2014). Entrepreneurial activities, being geographically mobile, are also thought to be a key driver of the structural transformation of local economies, easing the spatial reallocation of resources from less to more productive areas (World Bank, 2016).

\section{Place-based drivers of entrepreneurship}

In the last four decades, and given the greater availability of spatially disaggregated business creation data, many studies have described and 
explained the geographic patterns of entrepreneurship in different countries. These studies tend to confirm two stylized facts that are observed regardless of the national context. First, there are large subnational differences in the quantity and nature of entrepreneurial activity. Second, these geographical differences are persistent (Parker, 2009). The literature thus describes the existence of spatial clusters of entrepreneurship (Glaeser et al., 2010). In the research for explanations to such subnational differences, empirical studies have explored place characteristics conditioning local entrepreneurial activity levels, focusing on what are sometimes called the "entrepreneurial framework conditions" (Levie \& Autio, 2007). Several factors have been emphasized including demographic and socioeconomic differences, local industrial structures, the size and dynamics of local demand, the stock of infrastructure and the availability of business support services. A classical example is the study by Reynolds et al. (1995), who analyzed fifteen entrepreneurship "processes" (explanatory variables) and their relation to the rate of business creation between 1976 and 1988 at the level of labor market areas of the United States. The authors conclude that the factors with a stronger explanatory power are industrial diversity, population growth, local household incomes (size of the local market), demographic structure (share of population in mid-career), and low unemployment (a signal of local economic dynamism).

Glaeser et al. (2010) summarize explanations regarding the geography of entrepreneurship according to four, not mutually exclusive, types of hypotheses. The first type involves places that offer greater returns for potential entrepreneurs. The second focuses on places offering lower business costs. The third includes localities endowed with natural and urban amenities that attract potential entrepreneurs and employees. The fourth represents places with greater levels of human capital. The analysis of data from the

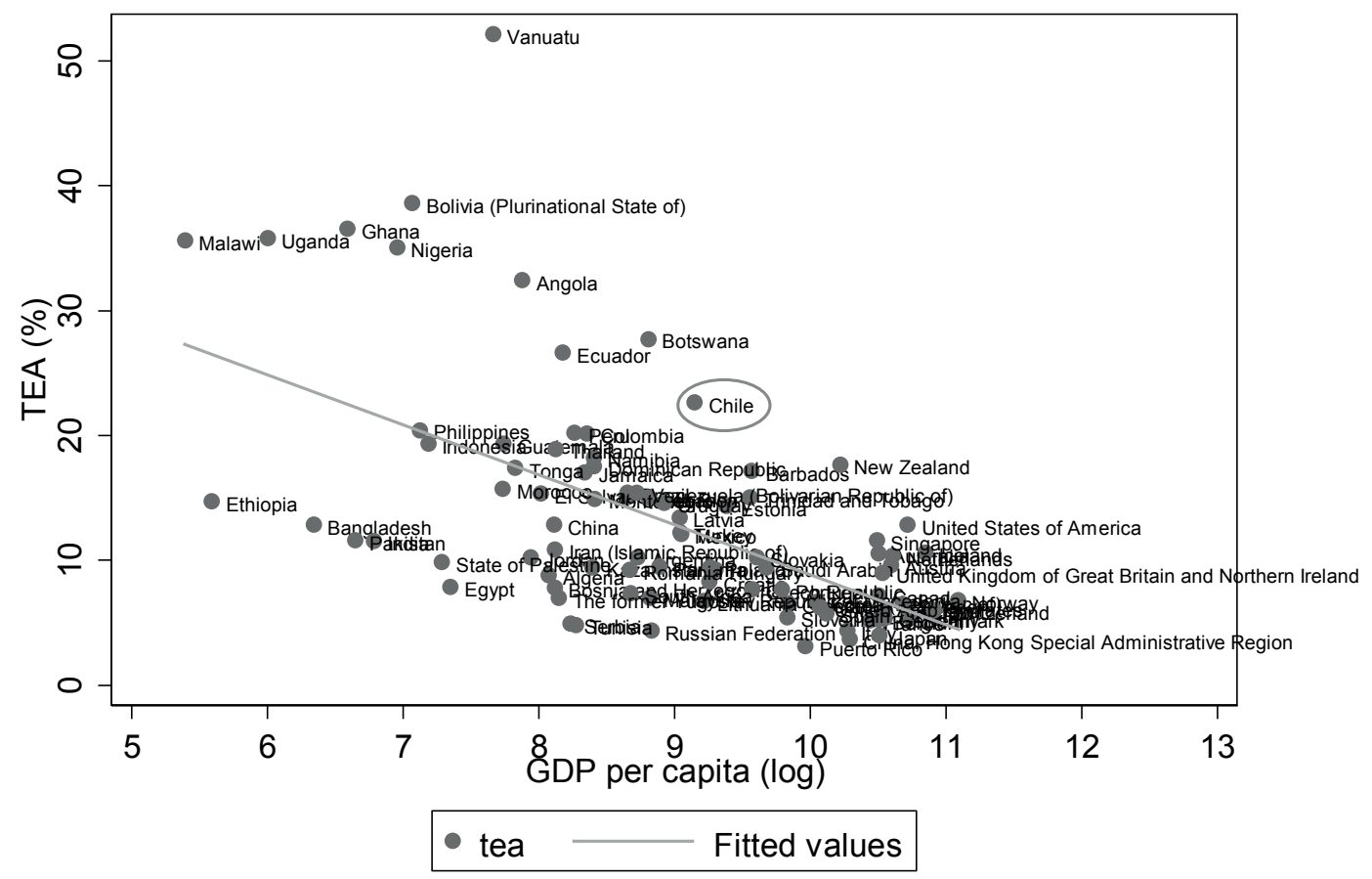

Figure 1. Total early-stage entrepreneurial activity (TEA) and economic development (2012). Note: TEA $=$ total entrepreneurial activity in initial phases. Source: Modrego et al. (2017a). 
United States suggests that lower business costs and greater human capital are the factors that best explain the spatial distribution of entrepreneurship.

There is still a limited number of studies regarding the geography of entrepreneurship in middleincome countries. In the case of Chile, Modrego et al. (2014) confirm a positive relation between business density and market access, a measure combining proximity and the size of surrounding markets. In another study, Modrego et al. (2017a) reinforce this finding from the perspective of nonagricultural self-employment rates. Their study demonstrates, however, that the benefits of greater market access are to some degree offset by higher wages (opportunity costs) in denser areas. Oyarzo et al. (2020) analyze a series of factors associated with the persistence of municipal differences in entrepreneurial activity and show the importance of industrial diversity, greater levels of urbanization, and an industrial structure with sectors that are less reliant on economies of scale. Amorós et al. (2013), on the basis of an experts' survey, conclude that remote and peripheral regions are perceived as providing unfavorable conditions for entrepreneurship, mainly due to a lack of financing and infrastructure.

Since the mid-1980s, revisiting a model from the previous century (see Marshall, 1890), new economic theories of location, mainly urban economics and the new economic geography (NEG), have substantially advanced our understanding of the spatial concentration of economic activity. Urban economics emphasizes advantages that are external to firms but internal to the place in which businesses are located. These advantages bring productivity gains and cost efficiencies and are known as "agglomeration economies" (Duranton \& Puga, 2004; Rosenthal \& Strange, 2004). Agglomeration economies in denser areas result, first, from input sharing. A larger and more diverse base of suppliers in denser areas allows firms to share transportation and coordination costs in procurement and to access more diverse and specialized inputs. The second source of agglomeration economies, labor pooling, arises from lower costs of searching and hiring workers. A denser and more diverse labor market allows a better match between specific skills required by businesses and those offered by workers, including individuals engaged in piecework labor with opportunities to sell their services across a larger number of firms. The third source is knowledge spillovers, which arise from a spatial concentration of knowledge sources that eases the generation, diffusion and absorption of new economic knowledge in denser, more complex and diverse social environments.

The new economic geography approach (most notably laid out in Fujita, et al., 1999, and Krugman, 1991) highlights the competitive advantages for businesses located close to large markets, which, on the one hand, face lower transportation costs and, on the other hand, can exploit internal economies of scale in larger markets. Entrepreneurs and capital are spatially mobile factors, and entrepreneurs will seek to exploit location advantages that allow firms to offer higher wages. A spatially mobile labor force will follow jobs and salaries that are concentrated in larger regions, which in turn leads to an increase in the demand for goods produced in such places and to higher business profits. These circular causation dynamics lead to an agglomeration process linking supply (firms) and demand (households), which self-reinforces with time and is known as the "home-market effect." This process of regional growth is one of the most convincing explanations to date of the evident spatial concentration of economic activity.

Recent studies have adapted these conceptual models to analyze the spatial patterns of entrepreneurship. Overall, they show that entrepreneurship responds to agglomeration economies and to selfreinforcing home market effects, a fact verified in diverse contexts such as Japan (Sato et al., 2012), Germany (Audretsch \& Fritsch, 1994) and Chile (Modrego et al., 2014; 2017a). In recent years, the academic literature has advanced the idea of a spatial sorting of entrepreneurship (Behrens 
et al., 2014; Behrens and Robert-Nicoud, 2015). The point here is that entrepreneurs sort themselves across the urban hierarchy (the system of cities based on size and complexity) driven by the returns they can obtain on their entrepreneurial human capital. When making location decisions, entrepreneurs balance the benefits of agglomeration economies and the disadvantages of congestion costs (e.g., land costs, commuting costs, labor costs). These theories predict that entrepreneurs with greater human capital (and therefore a higher probability of generating innovative new businesses) are those who locate in larger cities. Such cities offer greater returns on entrepreneurial skills and therefore allow more skilled entrepreneurs to offset the higher congestion costs. More relevant to rural development, according to the theory, entrepreneurs with lower levels of human capital are those who are more likely to remain in smaller cities and areas of lower population density, where they do not obtain as much return on their entrepreneurial human capital but where they can run profitable businesses due to the lower congestion costs. The evidence based on nonagricultural self-employment rates in many contexts shows low-skill entrepreneurship everywhere but in greater proportion in peripheral areas (Atienza et al., 2016).

The basic economic reasoning behind the spatial sorting of entrepreneurial human capital is consistent with the evidence of positive selection effects in the interregional mobility of human capital in migration studies, which shows that individuals with greater resources and skills tend to migrate the most (Cazzuffi \& Modrego, 2018). Nevertheless, the practical relevance of theories based on footloose entrepreneurs as a central explanation for the geography of entrepreneurship is subject to argument given the assumption that people move in search of better places to start businesses. Pioneering studies in the developed world portray entrepreneurship as an essentially local phenomenon. Michelacci and Silva (2007), for example, show that in Italy and the United States, entrepreneurship, particularly that which survives and grows, is largely carried out by locals. The study argues that locals are those who best know the economic opportunities that exist in their surroundings and who, by putting into play their human capital, networks and information, can access the necessary resources to start-up and oversee projects that thrive.

Finally, in recent decades, the academic and policy research has shown growing interest in systemic models of entrepreneurship. The most influential expression of this approach is currently the entrepreneurial ecosystems framework (Isenberg, 2010; 2011; Mason \& Brown, 2014). There are four central premises of this model (Pezzi \& Modrego, 2020). First, the ecosystem view underscores the recognition that entrepreneurial activity cannot be understood regardless of the context in which it develops. Second, the model incorporates the empirically supported observation that the most relevant context is the local/regional context. Third, the model acknowledges that the local ecosystem is made up of multiple elements that interact in complex ways; therefore, it is necessary to engage in the study and formulation of entrepreneurship policies holistically. Fourth, the entrepreneurial ecosystem analytical approach views the process of business and employment creation as an essentially dynamic phenomenon that arises and evolves through interactions among entrepreneurs, market conditions, and market outcomes. Isenberg (2011) identifies six key elements that must be present in the local entrepreneurial ecosystem to create an enabling environment: i) human capital, ii) dynamic markets, iii) entrepreneurship financing, iv) specialized entrepreneurship support services, v) enabling policies, and vi) an entrepreneurial culture. The entrepreneurial ecosystems model thus predicts that the performance of a local entrepreneurial ecosystem will be limited by its weakest element and that without these six conditions in place, it will be unlikely that regions will achieve a qualitative leap in their entrepreneurial performance (Isenberg, 2010). 
The entrepreneurial ecosystems approach has been criticized as incomplete and somewhat static, still immature in its conceptual development and lacking a basis of empirical evidence supporting it (Stam, 2015; Roundy et al., 2018). Nevertheless, the six elements proposed by Isenberg (2011) seem to encompass a comprehensive set of necessary ecosystem conditions for the emergence of innovative entrepreneurship. Furthermore, the promotion of a holistic and systematic viewpoint continues to be considered a relevant advance in the understanding of entrepreneurship and for the effective design of support policies (Stam, 2015; Roundy et al., 2018).

From this review of the literature, one should conclude that rural entrepreneurship faces an adverse economic geography. Rural zones, which are relatively sparsely populated, distant from markets, and largely dependent on natural resource primary activities, appear to have limited potential to exploit the productivity and efficiency advantages related to more densely populated urban areas. As a result of their sparseness, lowdensity and remoteness, rural areas typically face worse entrepreneurial framework conditions such as less physical and communication infrastructure, a lack of financing and business support services, smaller and less diverse labor markets and limited access to suppliers of specialized services. In summary, ecosystem conditions in rural areas seem disadvantageous in comparison with urban zones.

Even so, in recent decades, studies in developed countries document a reverse trend of the relocation of urban populations to rural areas that are rich in natural amenities, largely in response to quality-of-life considerations (Rappaport, 2007). This relocation process has been accompanied by the rapid growth of many rural and semirural areas (Irwin et al., 2009). Particularly in the case of entrepreneurship, in EEUU (and in other countries), natural and cultural amenities have been a powerful attractor of creative human capital (or Florida's (2004) “creative class") to rural and semirural areas. In many contexts, these migrants, with new business ideas cultivated as a result of their urban background, have been initiators of innovative entrepreneurship closely linked to the traditional activities of the rural world (Anderson, 2000), especially when there are enabling framework conditions for entrepreneurship. This combination of amenities, framework conditions and creative human capital has been called the "rural development trifecta" (McGranahan et al., 2011) and in the medium term could be a potential lever for localized processes of rural development for countries of upper middle income, as in the case of Chile.

\section{Entrepreneurship in Chile: geographic patterns and rural entrepreneurial activity}

The literature review in the previous section presents a series of arguments on why innovative entrepreneurship in rural areas faces unfavorable structural conditions. In this section, we endeavor to show, using data from previous studies, that this is not necessarily the case in Chile. In particular, we demonstrate that rurality is not a burden per se for entrepreneurship and that, on the contrary, there is great potential to be unleashed by implementing adequate enabling policies.

However, before analyzing the geographic patterns of entrepreneurship in Chile, we first turn to discuss some measurement issues. As a direct consequence of the lack of a definitional consensus regarding entrepreneurship, different studies use different metrics of regional entrepreneurial activity (Faggian et al., 2019). Among the most popular metrics are the rates of nonfarm selfemployment, the rates of business creation, and the share of small businesses in the total number of firms. The practical problem is that different metrics usually portray very different geographies of entrepreneurship (Low \& Isserman, 2015). Because of this, when analyzing the spatial distribution of entrepreneurship, it is necessary to 
be explicit about what aspect of entrepreneurship the metric is actually measuring and to use that which best describes the phenomenon the analyst aims to address.

Nevertheless, there are several useful proxy variables to characterize the spatial distribution of innovative entrepreneurship in Chile, especially when analyzed jointly. Figure 2 shows the rate of self-employment out of agriculture in Chilean municipalities. The figure shows high levels of self-employment out of agriculture in several rural municipalities, entrepreneurship which adds to self-employment in agriculture. This pattern is observable in rural areas of Coquimbo and Valparaíso, south of Maule and Nuble, and in Araucanía, the poorest region in the country. In addition, Figure 3 shows that several communities with high rates of entrepreneurship are very rural and highly remote and poor such as
Los Sauces or Ercilla. This pattern is consistent with diverse studies showing the increasing importance of diversification out of agriculture as a source of income generation for rural households (Berdegué et al., 2004; Bentancor et al., 2008). Nevertheless, Figure 3 shows a general pattern in which there is no clear relationship between the share of the rural population in the municipality and entrepreneurship as measured by rates of self-employment out of agriculture.

Another study by Atienza et al. (2016) describes the geographic patterns of entrepreneurship according to certain entrepreneurial characteristics. The authors document a concentration of skilled, high-income self-employed individuals in some urban areas such as the northeast sector of the city of Santiago (the national capital city) and in the metropolitan area of Valparaíso and Viña del Mar, two other large cities nearby. On
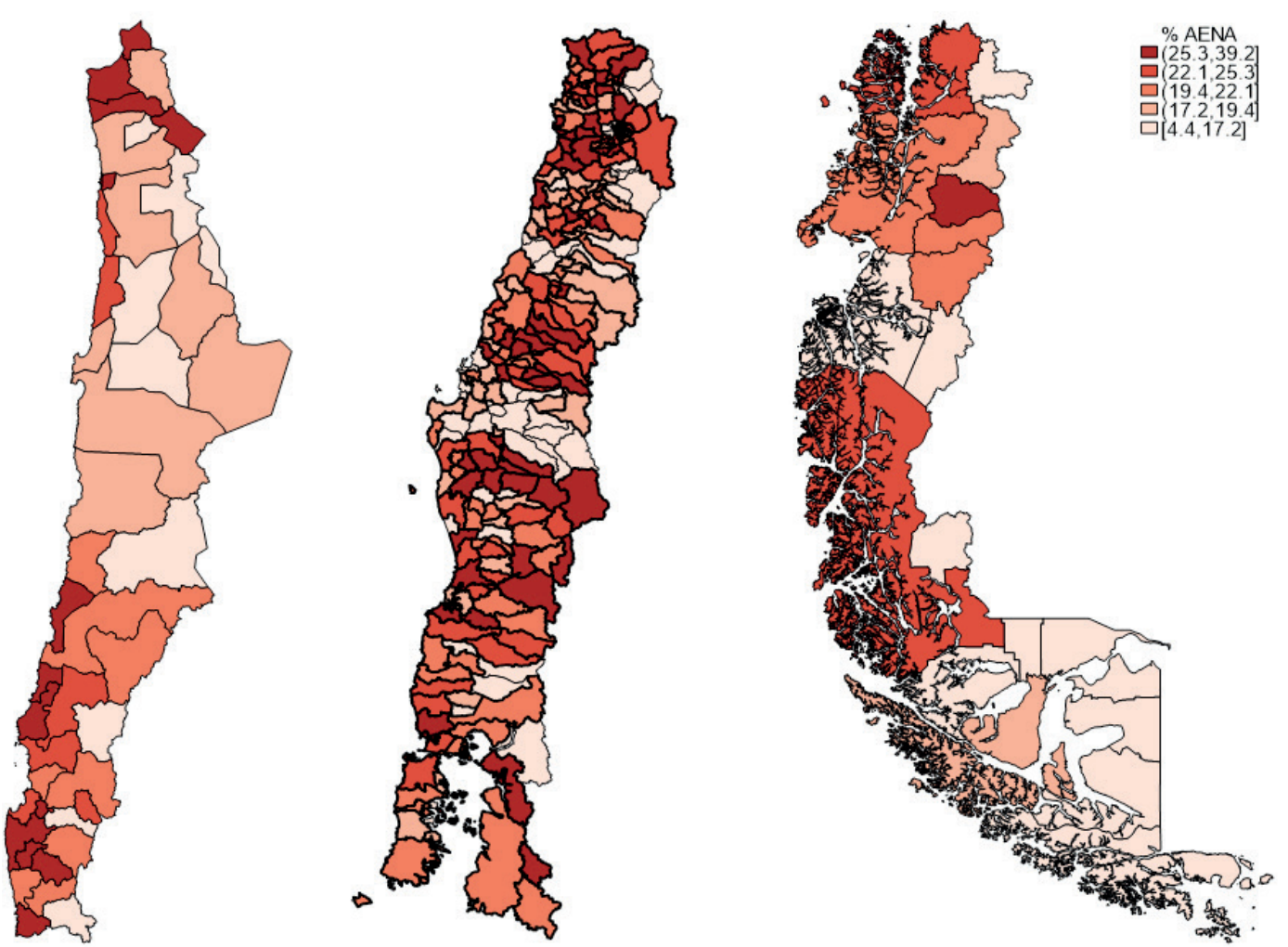

Figure 2. Rates of self-employment out of agriculture in Chilean municipalities.

Note: Rates of self-employment in the nonagricultural sector based on the 2002 population census. Source: Adapted from Modrego et al. (2017a). 


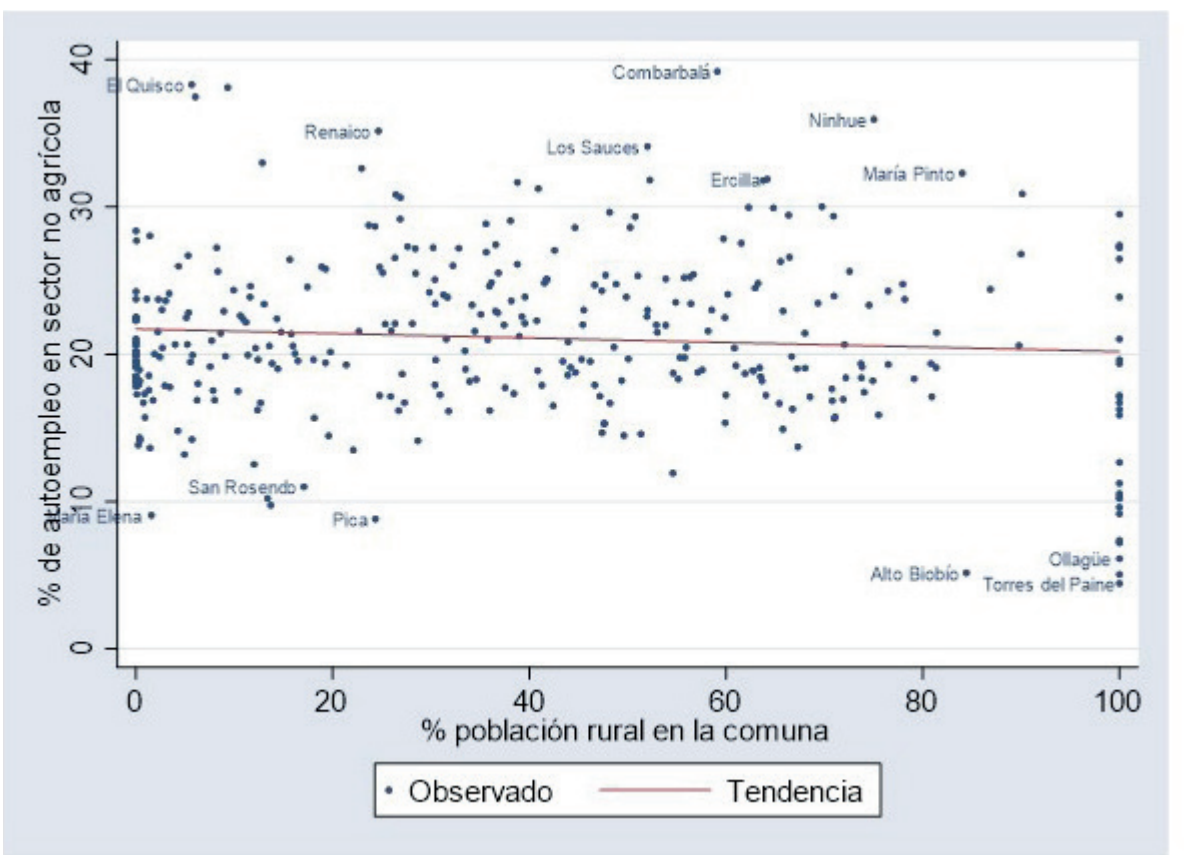

Figure 3. Rurality and entrepreneurship as rates of self-employment out of agriculture.

Note: Rurality and rates of self-employment out of agriculture based on the population census 2002. Intercept $=21,7$; slope $=$ -0.015 (not significant at the $5 \%$ level). $\mathrm{r} 2=0.007$. Source: Adapted from Modrego et al. (2017a).

the other hand, there is a cluster of unskilled, low-income self-employed individuals in rural areas of the Region of Araucanía. Despite the frequent high rates of self-employment in rural areas, the study by Atienza et al. (2016) concludes that entrepreneurship based on skilled human capital (presumably with greater potential for growth and innovation) would essentially be a phenomenon that is clustered in very specific urban areas of the country. In contrast, given the most common characteristics of the nation's entrepreneurs, the bulk of entrepreneurship in Chile, and especially in most rural areas, likely better fits the notion of entrepreneurship by necessity (Modrego et al., 2017b). This type of entrepreneurship is mostly driven by a lack of employment alternatives, which pushes people to start "subsistence" activities, mostly informal and with little growth and innovation ambition and potential.
Many rural areas with relatively high rates of selfemployment out of agriculture do not show high levels of entrepreneurial activity when measured by the rates of initiation of formal (tax-paying) economic activities (Figure 4). The rural areas of Araucanía and Ñuble, for example, are illustrative cases. This pattern is consistent with the conclusions of Atienza et al. (2016). Nevertheless, Figure 5 shows that although there is a negative general relationship between rurality and rates of entrepreneurial activity measured as new formal economic activities per thousand adults, this relation is not especially strong, and there are also several counterexamples. Several areas with relatively high rates of new economic activity are rural or semirural communities, which are usually rich in natural and/or cultural amenities and strongly oriented to tourism. Remarkable cases are Villarrica (an outlier not shown in the figure), Tortel and San Pedro de Atacama. 

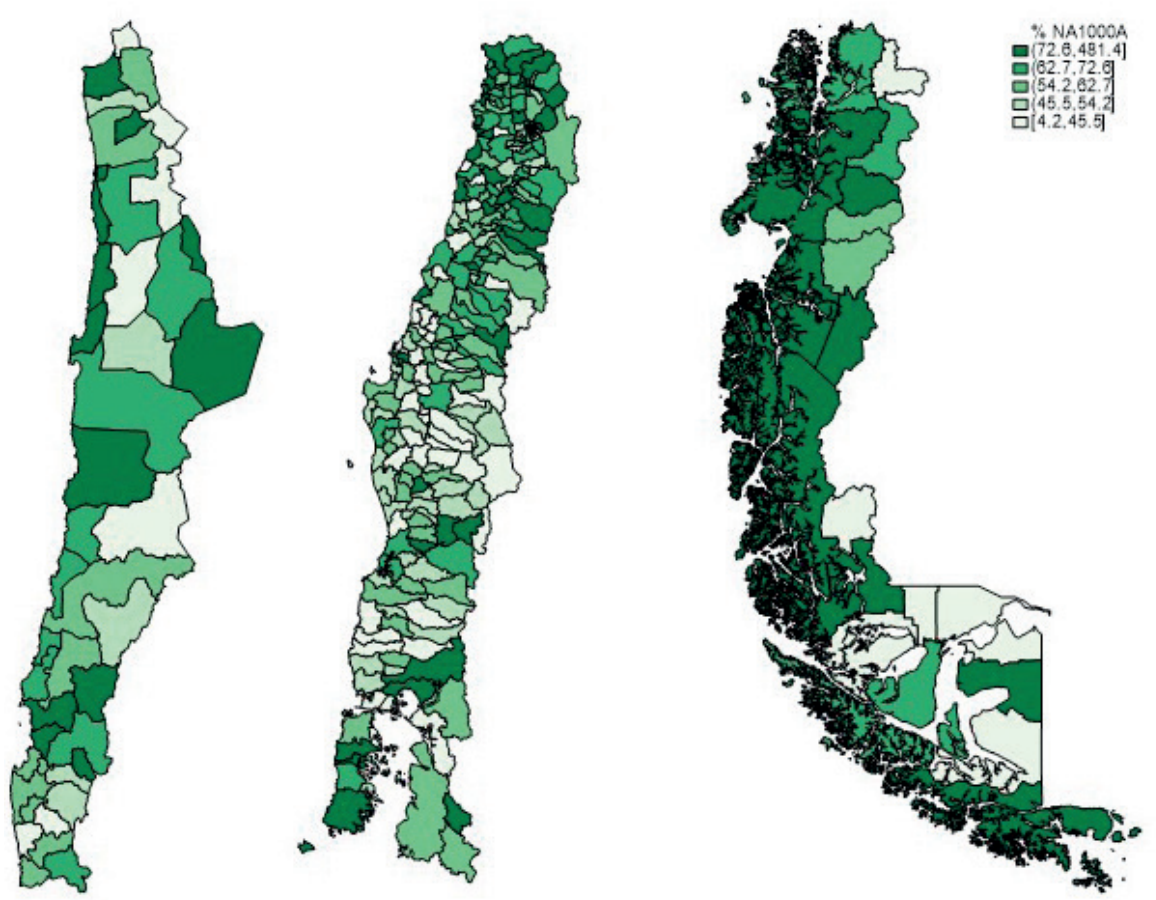

Figure 4. New formal economic activities created between 2002 and 2008 for every thousand adults in Chilean municipalities.

Note: New formal economic activities created between 2002 and 2008 based on SII data. Source: Adapted from Modrego et al. (2015).

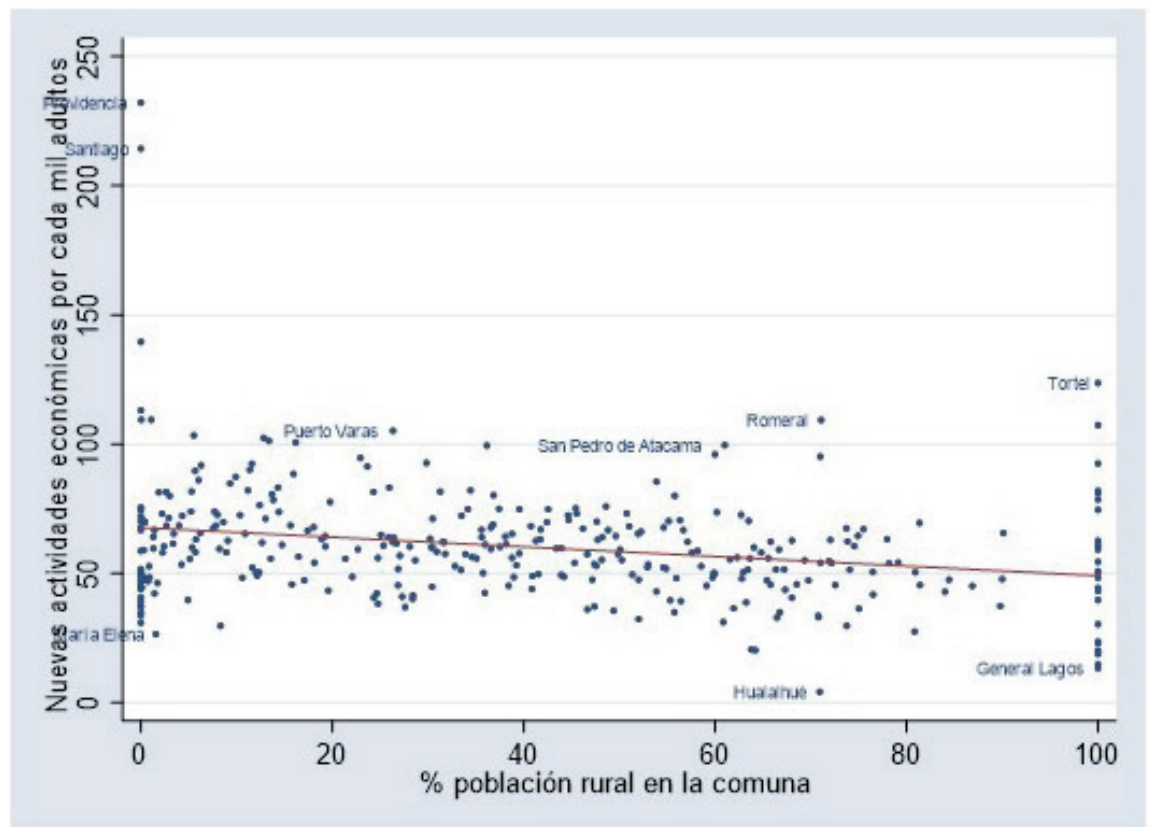

Figure 5. Rurality and entrepreneurial activity as new formal economic activities per thousand adults.

Note: New formal economic activities created between 2002 and 2008 based on SII data. Intercept $=69.3$; slope $=-0.195$ significant at the $1 \%$ level). $\mathrm{r} 2=0.035$. Source: Adapted from Modrego et al. (2015). 
In an ongoing study (Modrego, unpublished data, $2021^{1}$ ), analyze the geographic distribution of growth entrepreneurship, which refers to earlystage businesses with the capacity to survive and grow in sales and in employment (Acs et al., 2008). Growth entrepreneurship rates are proxied here by the number of new businesses that grew both in sales and in employment in the first five years relative to the total of new active businesses (i.e., reporting sales) created in the period. Figure 6 does not show a clear geographic pattern for the rates of growth entrepreneurship, suggesting that the idiosyncratic conditions of the localities may explain the different rates of successful entrepreneurship. After correlating this rate with the share of rurality (Figure 7), the pattern is again unclear. This result is worth noting: there is no evidence that rurality is per se a burden for earlystage firms to thrive.

From this analysis of the spatial patterns of entrepreneurship in Chile, it is clear that there is great entrepreneurial potential in the rural areas of the country generated by the relatively high levels of self-employment out of agriculture. However, due to the rural-urban gaps both in the levels of human capital and in the ecosystem or framework conditions, the bulk of the current rural entrepreneurship is presumably of limited innovation potential. Nevertheless, there are several reasons to nuance this assertion. First, one must take into account the dynamic effects of entrepreneurship, particularly at the local scale; entrepreneurs learn from experience, failures and successive business attempts in a process that is known as renascent entrepreneurship (Stam et al., 2008), and many successful businesses arise out of what had previously been much simpler and generally imitative endeavors (Feldman et al., 2005). In addition, in several rural areas, the creation of new formal economic activities is notably high, suggesting that there is incipient potential for amenity-based rural growth in many rural areas in Chile. This trend is more consolidated in higher-income countries, but it is also likely to grow in middle-income countries as they develop. Finally, early-stage firms in Chile's rural areas show a similar capacity for growth compared to those in urban areas, suggesting that rurality is not an obstacle for growth entrepreneurship. A sensible explanation for this fact can be found in recent models of agglomeration with heterogeneous agents in urban economics (Behrens et al., 2014; Behrens \& Robert-Nicoud, 2015). In addition to the agglomeration economies and the sorting of skilled individuals, in agglomerated areas, there is also tougher competition. This is because of the larger number of firms and entrepreneurs competing in the market and because entrepreneurs are selected from a pool of more skilled individuals who tend to sort themselves into larger regions. In such competitive conditions, the level of entrepreneurial skills required to succeed is higher, and a larger share of entrepreneurs is filtered out by competition. The balance among agglomeration economies, skill-based spatial sorting, and occupational selection may well lead to a geography of GE where rural new businesses do as well as their counterparts in urban areas.

\section{Conclusions and recommendations for policies to promote rural entrepreneurship}

This essay has argued that there is potential for greater and more innovative entrepreneurship in the rural areas of Chile and other middle-income countries. It also offers some guidelines for rural development policies to unleash this entrepreneurial potential. A review of the scientific literature, summarized in Table 1, shows that entrepreneurship is a complex and diverse phenomenon and

\footnotetext{
1 This ongoing project is joint work with M. Atienza and L. Hernández, titled " Growth entrepreneurship in a less-developed country: where do they all belong?"
} 

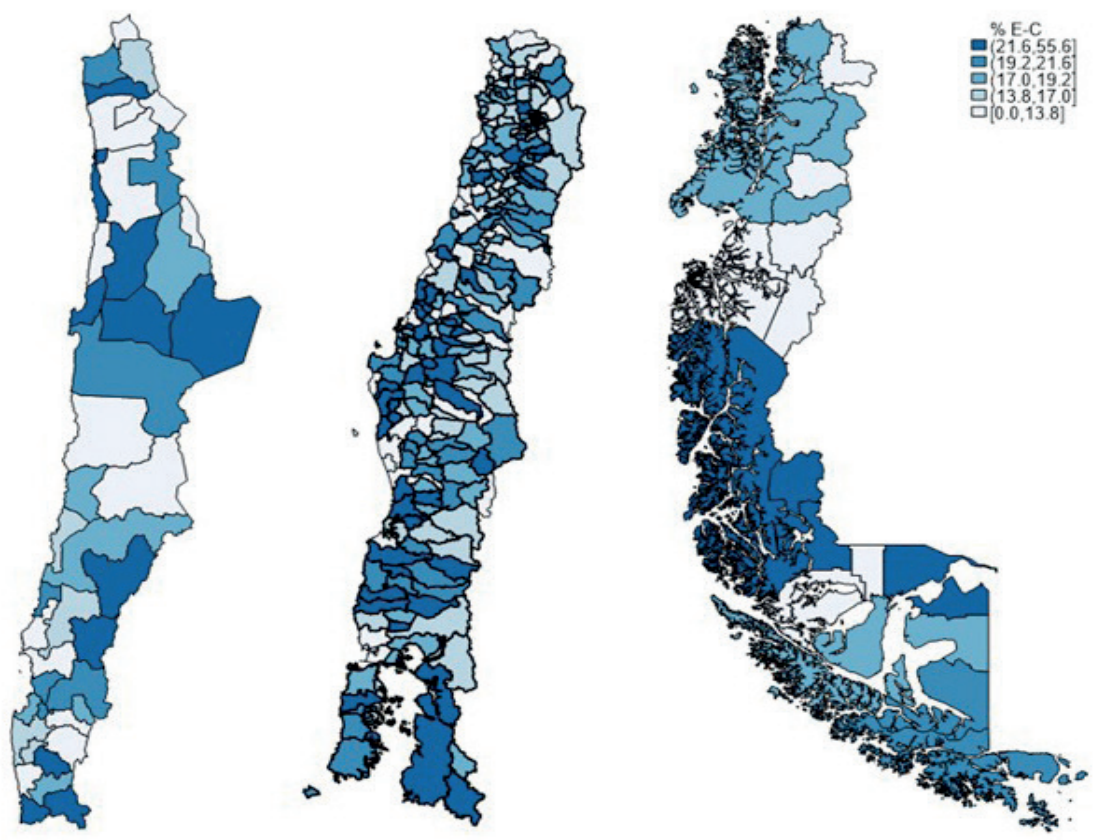

Figure 6. Rates of growth entrepreneurship by municipality in Chile.

Note: Rates of growth entrepreneurship over the total number of active formal businesses created between 2005 and 2015 based on SII data. Source: Adapted from work in progress by Modrego, F., Atienza, M., Hernández, L., (2021), "Growth entrepreneurship in a less-developed country: where do they all belong?"

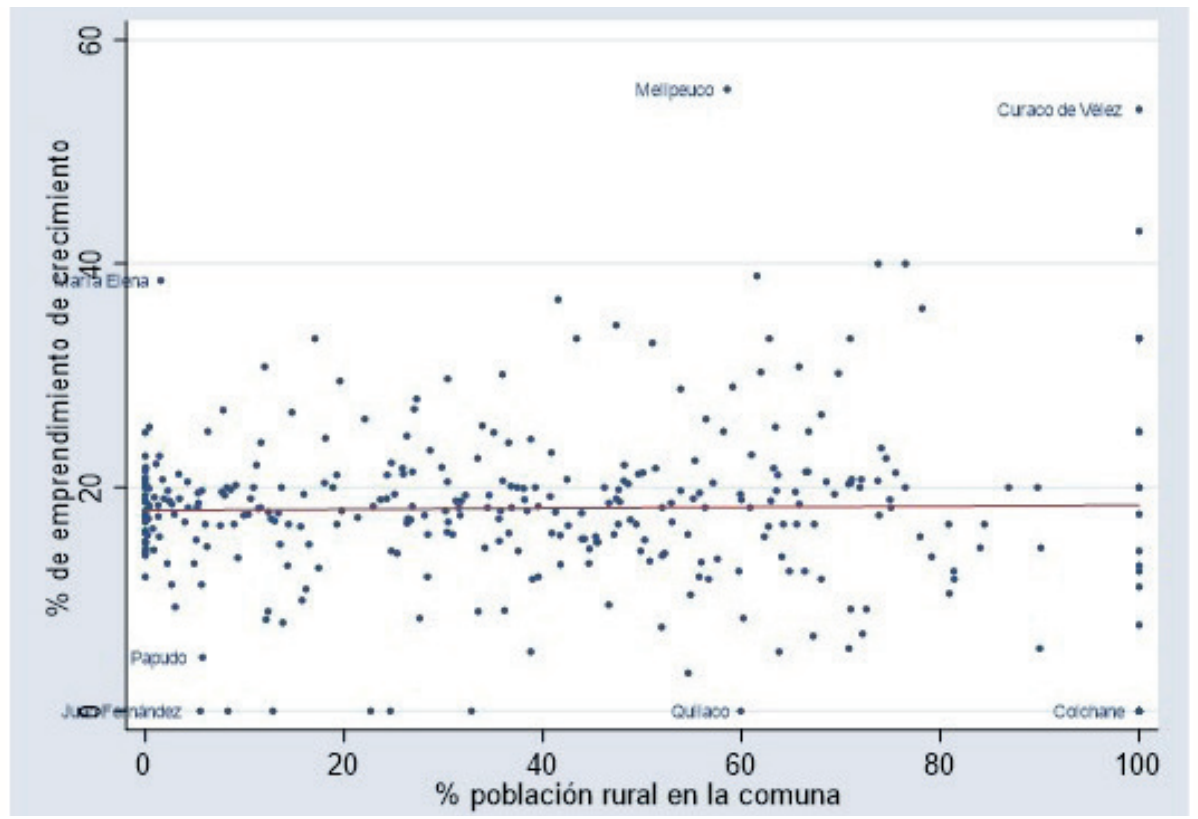

Figure 7. Rurality and rates of growth entrepreneurship.

Note: Rurality according to 2002 census. Rate of growth entrepreneurship as percentage of new active businesses that grew in sales and employment in their first five years (SII data). Intercept $=17,9 ;$ slope $\mathrm{t}=0.005$ (not significant at the $5 \%$ level). $\mathrm{r} 2=$ 0.0003. Source: Adapted from work in progress by Modrego, F., Atienza, M., Hernández, L., (2021), "Growth entrepreneurship in a less-developed country: where do they all belong?" 
that different types of entrepreneurship can contribute to different development objectives. An immediate implication is that policies aimed at the promotion of entrepreneurship should avoid an excessive focus on entrepreneurship that is intensive in technically sophisticated knowledge and innovative in the conventional sense of being avant-garde, a perception bias that has long dominated the intellectual and policy debate over entrepreneurship. In contrast, less sophisticated entrepreneurship, one that rural areas in Chile could currently foster, should also be acknowledged and supported. Rural entrepreneurship can contribute significantly to the incomes of rural households and be a catalyst for the structural transformation of local rural economies in the medium and long term.

Current theories of location and entrepreneurship emphasize the importance of local frameworks or ecosystem conditions and the importance of economic geography to explain the spatial distribution of entrepreneurship and how rural areas are placed in this geography. The conclusion is that, ceteris paribus, rural zones face a seemingly adverse economic geography given their distance to large markets, lower levels of human capital, lack of agglomeration economies and absence of certain enabling factors for entrepreneurship in general and for innovative entrepreneurship in particular.

Table 1. A roadmap to key scientific literature on entrepreneurship

\begin{tabular}{|c|c|c|}
\hline Topic & Articles & Contribution \\
\hline \multirow[t]{2}{*}{ Definition of entrepreneurship } & Hébert and Lynk (1989). & $\begin{array}{l}\text { Comprehensive definition of } \\
\text { entrepreneurship. }\end{array}$ \\
\hline & Wennekers, and Thurik (1999). & $\begin{array}{l}\text { Comprehensive definition of } \\
\text { entrepreneurship. }\end{array}$ \\
\hline \multirow[t]{2}{*}{ Heterogeneous entrepreneurship } & Birch (1981) & Typology of entrepreneurial firms \\
\hline & $\begin{array}{l}\text { Reynolds et al. (2005) } \\
\text { Acs et al., (2008) }\end{array}$ & $\begin{array}{l}\text { Opportunity and necessity-driven } \\
\text { entrepreneurship. }\end{array}$ \\
\hline \multirow{2}{*}{$\begin{array}{l}\text { Roles of entrepreneurship in } \\
\text { development }\end{array}$} & Carree and Thurik (2003); Parker (2018) & Comprehensive analytical review. \\
\hline & Naudé (2010) & Focus on developing countries. \\
\hline \multirow[t]{6}{*}{$\begin{array}{l}\text { Territorial drivers of } \\
\text { entrepreneurship }\end{array}$} & Reynolds et al. (1995); Glaeser et al. (2010) & $\begin{array}{l}\text { Empirical evidence on a broad array of place- } \\
\text { based drivers of entrepreneurship. }\end{array}$ \\
\hline & $\begin{array}{l}\text { Sato et al., (2012); Modrego et al., (2014; } \\
\text { 2017a) }\end{array}$ & $\begin{array}{l}\text { Evidence of market size effects on } \\
\text { entrepreneurship rates. }\end{array}$ \\
\hline & Behrens et al. (2015); Behrens et al. (2014) & $\begin{array}{l}\text { Interactions between agglomeration } \\
\text { economies, spatial sorting and occupational } \\
\text { selection as determinants of the spatial } \\
\text { distribution of entrepreneurship. }\end{array}$ \\
\hline & Parker (2005) & $\begin{array}{l}\text { Path-dependencies in regional } \\
\text { entrepreneurship. }\end{array}$ \\
\hline & Isenberg (2010) & Foundations of the systemic approach. \\
\hline & McGranahan et al. (2011) & $\begin{array}{l}\text { Evidence of an amenity and entrepreneurship- } \\
\text { based rural growth. }\end{array}$ \\
\hline \multirow[t]{2}{*}{ Entrepreneurship policy } & Welter et al. (2016), Kuratko et al., (2021). & $\begin{array}{l}\text { Inclusive approach to entrepreneurship } \\
\text { policy-making. }\end{array}$ \\
\hline & Isenberg (2011); Mason and Brown (2014) & $\begin{array}{l}\text { Systemic and place-based approach to } \\
\text { entrepreneurship policy. }\end{array}$ \\
\hline
\end{tabular}


In this regard, beyond the expectations imposed on them, it is unlikely that policies of physical and virtual connectivity alone could solve these problems. Evidence in other contexts (primarily Europe) shows that investment in the development of transportation infrastructure can ultimately strengthen the forces underlying agglomeration in larger regions and exacerbate regional disparities (Puga, 2002). Similarly, the evidence also shows that policies for the provision of information and communication infrastructure have not always by themselves boosted the development of rural entrepreneurship in communities where there is no pre-existing entrepreneurial dynamism, as shown, for example, by Cumming and Johan (2010) in the case of rural internet in Canada.

Similarly, policies for the formation of rural human capital, implemented in isolation, may do nothing more than encourage rural people's mobility (particularly of young people) to urban areas, where beneficiaries can obtain a better return on human capital investments; or, put differently, more resources for more and better schooling can reinforce the documented positive selection effects of human capital on interregional migration (e.g., Cazzuffi \& Modrego, 2018). In any case, investments in the human capital of rural young people yield returns perhaps not realized in full until 10 to 20 years in the future. Both the mobility-migration effect and the delayed-return effect make it unlikely that an increase in the coverage and quality of rural education would stimulate innovative entrepreneurship (and, more generally, local development) if not coupled with policies that enhance economic opportunities in local communities.

The overall conclusion is that the promotion of rural entrepreneurship requires strategies that are integrated and that exploit the synergies and complementarities between sectorial policies and between policies and the specific features of places. As mentioned above, the intellectual debate on entrepreneurship has increasingly shifted toward holistic and systemic approaches to the understanding and promotion of entrepreneurship. In this view, the central premise for the design of policies is the development of enabling local environments. Key elements emphasized in the literature are markets, human capital, entrepreneurship funding, specialized support services, sound economic policies and the promotion of a local entrepreneurial culture. The focus on building an entrepreneurial ecosystem emphasizes that all these elements must be strengthened jointly because the final outcomes will be determined by the weakest element of the system.

The systemic viewpoint can help in defining some general principles to inform initiatives in support of rural entrepreneurship such as the adoption of a territorial approach that eases the articulation of different actors and sectorial policies, reducing problems of coordination and strengthening rural entrepreneurial ecosystems in their different elements and relationships. As acknowledged by influential scholars and multilateral institutions, a territorial approach allows for incorporation in the design and implementation of rural entrepreneurship support policies the heterogeneity of local institutional, geographical, political and cultural conditions in which the policy unfolds (Barca et al., 2011). These differences are key in understanding the spatial differences in entrepreneurial activity as the consequence of path-dependent processes (e.g., Parker, 2005) mediated by history, context and institutions. Thus, the territorial approach may facilitate the identification and activation of idiosyncratic territorial levers of rural entrepreneurship, which influence economic outcomes above and beyond entrepreneurs' individual differences (de Ferranti et al., 2006). Thus, a territorial approach to rural entrepreneurship policy can decisively contribute to unleashing the development potential that exists in rural regions while addressing policy objectives aimed at achieving more evenly distributed outcomes across distinct territories (OECD; 2012).

In addition, a necessary condition for any entrepreneurial ecosystem is entrepreneurial human capital, 
and, as has been documented here, rural areas already provide a foundation upon which to build. The data in Chile show that there is a high rate of nonfarm self-employment in rural areas, in addition to the high rates of self-employment in agriculture. This rural self-employment represents a stock of entrepreneurial human capital already forged in experience, although its activities are still likely mostly of the necessity type. Re-entrepreneurship (Stam et al., 2008) and serial entrepreneurship (Parker, 2013) are well documented mechanisms of entrepreneurial upgrading of the "learning by doing" type and provide a basis for the escalation of current rural entrepreneurship toward one of greater sophistication and more innovation in a broader sense. Even when many individual rural entrepreneurships do not reach a significant scale or complexity, the added effect of many small rural endeavors can be substantial in terms of income generation and local economic growth in the medium and long term. In more dynamic terms, rural entrepreneurs have the potential to reshape their local economies, perhaps at a slower pace and in a different qualitative form than entrepreneurship in innovative cities, but certainly in a significant way.

Finally, demographic trends that are still incipient in middle-income countries such as Chile but that are already consolidated in developed economies can constitute, in the not-so-long term, a driver for amenity-based local rural growth. An example is the city-to-countryside reverse mobility of qualified human capital in search of a better quality of life. As has been established here, many of Chile's rural areas that are rich in natural amenities already show substantial entrepreneurial dynamism. Therefore, there is evidence for the development of policies that can spur localized growth processes through the provision of urbanlike amenities, public goods and local public services in the rural environment.

Institutions and policies can accelerate or slow the virtuous cycle processes of rural entrepreneurship. Currently, rural entrepreneurship in Chile faces a fragmented institutional design, with agencies devoted to the promotion of business productivity on the one hand (e.g., via SERCOTEC and CORFO) and to the promotion of the agri-food sector on the other (e.g., via INDAP and FIA) (see Box 1). Each institution has its own logic, tools and scope of competence. With the recently enacted National Rural Development Policy, decisionmakers have opened the door for the Ministry of Agriculture and its agencies to play a leading role in addressing problems of coordination and institutional fragmentation.

When designing policies to promote rural entrepreneurship, policy-makers should avoid creating obstacles by imposing unnecessary restrictions on access to assistance from agencies that are typically focused on agricultural activities. The Institute of Agriculture and Livestock Development (INDAP), for example, could take advantage of its territorial reach and embeddedness, its network of technical assistance suppliers, and, more generally, its institutional capital to act as an incubator of rural entrepreneurship. This incubation role could go much further than agritourism and the small-scale artisan food activities that INDAP currently promotes. The institution could assist, for example, the development of viable entrepreneurship in services related to transportation, mechanics, construction, and other areas, activities that are already developed by small-scale entrepreneurs in rural areas without much public assistance. A priori, the only normative constraint to INDAP's support of entrepreneurship should be the rural location of the business, not a particular economic sector. Thus, INDAP could serve as a bridge for small, rural endeavors to access other government assistance agencies, acting as an intermediary linking rural entrepreneurs to the broader support system in the Ministry of Economy, which does not easily reach this segment of businesses. Similarly, the assistance portfolio of the Ministry of Agriculture, especially through INDAP, could contemplate expanding its instruments to the formation of general skills for entrepreneurship such as strategy development, business management, 
accounting and skills to navigate the bureaucratic labyrinth associated with issues including taxes, regulations, and patents. Furthermore, in the post pandemic world, there will be an increased need for strengthening skills in digital and remote work, and the rural environment will potentially become more attractive for this type of activity. Given its current mandate, for INDAP to assume these new roles would likely require an organic legal change that allows the agency to expand its scope of intervention. However, this could be a necessary change to advance toward a more versatile institution for the rural economy of the XXI century.

Other ministry institutions can also collaborate with rural entrepreneurship. The Agriculture and Livestock Service (SAG) can strengthen its efforts and outreach through initiatives related to information and training in legal norms for protecting renewable natural resources such as wildlife, native forests, agricultural land and fisheries. These are norms that affect all types of entrepreneurial activities developed in rural areas. In addition, small-scale entrepreneurs entering the food sector must fulfil the norms and audit controls of the Health Ministry. The fixed costs associated with the fulfilment of these types of regulation are a heavy load for small companies and represent barriers to entry, especially for initial endeavors. SAG could devote greater efforts to assist this segment of the rural world, thereby contributing to significant reductions in the costs of entrepreneurship in rural areas.

Similarly, the Foundation for Agrarian Innovation (FIA) can strengthen its role as an articulator of regional systems of innovation with a focus on bridging the rural world if it expands the scope of its interventions with projects that are more strategic and that link other productive areas (e.g., engineering) to rural entrepreneurship. In addition, FIA can implement initiatives for the formation of innovation skills (e.g., creativity, active learning, leadership), for linking rural entrepreneurs to sources of knowledge generation (universities, research centers), and for achieving broader institutionalization to promote rural innovative entrepreneurship in lagging regions.

All of these proposals fit well within the new National Policy of Rural Development. This is an indicative policy that seeks to promote the development of rural opportunities (in a broad sense) through the articulation of multisectoral initiatives for the rural economy, which is deemed to be more complex and more diverse than traditionally acknowledged by analysts and policy-makers.

\section{Acknowledgements}

The authors are grateful to two anonymous reviewers for their insightful comments and suggestions. Any error is solely the authors' responsibility. Jorge Ortega and Francisco Jiménez provided excellent research assistance. Modrego wishes to thank the support of the Chilean National Agency of Research and Development (ANID) through the FONDECYT Initiation in Research Fund 2019 [Grant: 11190112].

\section{Resumen}

F. Modrego, y W. Foster. 2021. Emprendimiento rural innovador en Chile. Int. J. Agric. Nat. Resour. 149-170. Políticas exitosas para fomentar el emprendimiento rural requieren un modelo conceptual consistente con las características de los espacios rurales y libre de estereotipos sobre el emprendimiento solo como tecnológicamente sofisticado. El objetivo de este ensayo es, primero, argumentar que las zonas rurales pueden ser un suelo fértil para actividades emprendedoras en países de ingreso medio como Chile y, segundo, discutir opciones de políticas para alcanzar el objetivo de estimular un emprendimiento más innovador 
en zonas rurales. Se revisa la literatura científica sobre emprendimiento y las definiciones, tipos y roles del emprendimiento en el desarrollo. Se resume la literatura sobre localización del emprendimiento para entender los motores de las diferencias territoriales de actividad emprendedora observadas. Una conclusión es que las zonas rurales enfrentan una geografía económica (aparentemente) adversa para el emprendimiento, aunque existe una tendencia reciente a un crecimiento impulsado por amenidades. A continuación, presentamos la geografía del emprendimiento rural en Chile. Contrario a la noción común, las tasas de emprendimiento en las zonas rurales de Chile son altas, aunque presumiblemente de un limitado potencial de crecimiento en las condiciones actuales. No obstante, esta base emprendedora provee un stock de conocimiento desde el cual se puede alcanzar una mayor sofisticación, y se discuten enfoques de política para estimular un emprendimiento rural más innovador. En el caso de Chile, las opciones de política disponibles son coherentes con la Política Nacional de Desarrollo Rural promulgada recientemente. Un enfoque sistémico, basado en amenidades, da a los países de ingreso medio oportunidades para el desarrollo de un emprendimiento rural más innovador mediante políticas que provean bienes públicos locales y mejoren las condiciones de vida.

Palabras clave: Desarrollo territorial, emprendimiento, geografía económica, política de desarrollo rural.

\section{References}

Acs, Z.J., Parsons, W., \& Tracy, S. (2008). Highimpact firms: Gazelles revisited. Office of Advocacy of the United States Small Business Administration (SBA).

Amorós, J.E., Felzensztein, C., \& Gimmon, E. (2013). Entrepreneurial opportunities in peripheral versus core regions in Chile. Small Business Economics, 40(1), 119-139.

Anderson, A.R. (2000). The protean entrepreneur: the entrepreneurial process as fitting self and circumstance. Journal of Enterprising Culture, 8(3), 201-234.

Audretsch, D.B., \& Fritsch, M. (1994). The geography of firm births in Germany. Regional Studies, 28(4), 359-365.

Audretsch, D.B., \& Keilbach, M. (2004). Entrepreneurship and regional growth: an evolutionary interpretation. Journal of Evolutionary Economics, 14(5), 605-616.

Atienza, M., Lufín, M., \& Romaní, G. (2016). Un análisis espacial del emprendimiento en Chile: Más no siempre es mejor. Eure, 42(127), 111135 .

Behrens, K., Duranton, G., \& Robert-Nicoud, F. (2014). Productive cities: Sorting, selection, and agglomeration. Journal of Political Economy, 122(3), 507-553.

Behrens, K., \& Robert-Nicoud F. (2015). Agglomeration theory with heterogeneous agents. In Duranton, G., Henderson V., \& Strange W. (Eds.) Handbook of Regional and Urban Economics, Volume 5A (pp. 171-246). Elsevier, North Holland.

Bentancor, A., Modrego, F., \& Berdegué, J. (2008). Crecimiento agrícola y pobreza rural en Chile $y$ sus regiones. (Documento de trabajo no. 6). RIMISP-Centro Latinoamericano para el Desarrollo Rural.

Berdegué, J., Ramírez, E., Reardon, T., \& Escobar, G. (2004). Empleo e ingresos rurales no agrícolas en Chile. In Empleo e ingresos rurales no agrícolas en América Latina. Cepal. LC/L. 2069-P-2004, 35-54.

Birch, D. L. (1981). Who creates jobs? The Public Interest, 65, 3-14.

Bosma, N., Stam, E., \& Schutjens, V. (2011). Creative destruction and regional productivity growth: evidence from the Dutch manufacturing and services industries. Small Business Economics, 36, 401-418.

Braunerhjelm, P., Acs, Z.J., Audretsch, D.B., \& Carlsson, B. (2010). The missing link: knowl- 
edge diffusion and entrepreneurship in endogenous growth. Small Business Economics, 34, 105-125. https://doi.org/10.1007/s11187-0099235-1

Brixy, U. (2014). The significance of entry and exit for regional productivity growth. Regional Studies, 48(6), 1051-1070.

Callejón, M., \& Segarra, A. (1999). Business dynamics and efficiency in industries and regions: The case of Spain. Small Business Economics, 13, 253-271.

Caves, R. E. (Ed.). (1992). Industrial Efficiency in Six Nations. MIT Press.

Carree, M.A., \& Thurik, A.R. (2003). The impact of entrepreneurship on economic growth. In Acs, Z.J. \& Audretsch, D.B. (Eds.). Handbook of entrepreneurship research (pp. 437-471). Kluwer Academic Publishers.

Cazzuffi, C., \& Modrego, F. (2018). Place of origin and internal migration decisions in Mexico. Spatial Economic Analysis, 13(1), 80-98.

Cumming, D., \& Johan, S. (2010). The differential impact of the internet on spurring regional entrepreneurship. Entrepreneurship Theory and Practice, 34(5), 857-884.

De Ferranti, D., Perry, G. E., Foster, W., Lederman, D., \& Valdés, A. (2006). Beyond the city: the rural contribution to development. Latin American and Caribbean Studies. World Bank.

Duranton, G., \& Puga, D. (2004). Micro-foundations of urban agglomeration economies. In Handbook of regional and urban economics (Vol. 4, pp. 2063-2117). Elsevier.

European Council (2013). Recommendation on establishing a Youth Guarantee, Official Journal of the European Union C, 120, 1.

Faggian, A., Modrego, F., \& McCann, P. (2019). Human capital and regional development. In $\mathrm{Ca}$ pello, R. and Nijkamp, P. (Eds.), Handbook of regional growth and development theories (2nd ed., pp. 149-171) Edward Elgar: Cheltenham, U.K.

Feldman, M., Francis, J., \& Bercovitz, J. (2005). Creating a cluster while building a firm: Entrepreneurs and the formation of industrial clusters. Regional Studies, 39(1), 129-141.
Florida, R. (2004). The rise of the creative class and how it's transforming work, leisure, community and everyday life (Paperback Ed.). Basic Books.

Fujita, M., Krugman, P.R., \& Venables, A. (1999). The spatial economy: Cities, regions, and international trade. MIT press.

Geroski, P.A. (1990). Innovation, technological opportunity, and market structure. Oxford Economic Papers, 42, 586-602.

Haltiwanger, J., Jarmin, R., \& Miranda, J. (2012). Who creates jobs? Small vs. large vs. young. (NBER Working Paper 16300). National Bureau of Economic Research.

Irwin, E.G., Bell, K.P., Bockstael, N.E., Newburn, D.A., Partridge, M.D., \& Wu, J. (2009). The economics of urban-rural space. Annual Review of Resource Economics, 1(1), 435-459.

Isenberg, D.J. (2010). How to start an entrepreneurial revolution. Harvard Business Review, 88(6), 40-50.

Isenberg, D.J. (2011). The entrepreneurship ecosystem strategy as a new paradigm for economic policy: Principles for cultivating entrepreneurship. Presentation at the Institute of International and European Affairs, Dublin, Ireland, 12 May 2011.

Kerr, W., \& Nanda, R. (2009). Financing constraints and entrepreneurship. (NBER Working Paper w15498). National Bureau of Economic Research.

Kirzner, I.M. (1979). Perception, opportunity, and profit: Studies in the theory of entrepreneurship, Chicago: University of Chicago Press.

Knight, F.H. (1921). Risk, uncertainty and profit, New York: Houghton Mifflin.

Krugman, P. (1991). Increasing returns and economic geography. Journal of political economy, 99(3), 483-499.

Kuratko, D.F., \& Audretsch, D.B. (2021). The future of entrepreneurship: the few or the many? Small Business Economics. https://doi.org/10.1007/ s11187-021-00534-0

Leibenstein, H. (1966). Allocative efficiency vs. xefficiency. American Economic Review, 56 (3), 392-415.

Li, M., Goetz, S.J., Partridge, M., \& Fleming, D.A. (2016). Location determinants of high-growth 
firms. Entrepreneurship \& Regional Development, 28(1-2), 97-125.

Low, S.A., \& Isserman, A.M. (2015). Where are the innovative entrepreneurs? Identifying innovative industries and measuring innovative entrepreneurship. International Regional Science Review, 38(2), 171-201.

Malecki, E.J. (2018). Entrepreneurs, Networks, and Economic Development: A Review of Recent Research. In Katz, J.A. and Corbett, A.C. (Ed.), Reflections and Extensions on Key Papers of the First Twenty-Five Years of Advances: Advances in Entrepreneurship, Firm Emergence and Growth, Vol. 20 (pp. 71-116), Emerald Publishing Limited, Bingley. https://doi.org/10.1108/ S1074-754020180000020010

Mason, C., \& Brown, R. (2014). Entrepreneurial ecosystems and growth oriented entrepreneurship. Paper prepared for the workshop organized by the OECD LEED Programme and the Dutch Ministry of Economic Affairs, November 2013. www.oecd .org/cfe/ leed/ Entrepreneurial-ecosystems.pdf

McGranahan, D.A., Wojan, T.R., \& Lambert, D.M. (2011). The rural growth trifecta: outdoor amenities, creative class and entrepreneurial context. Journal of Economic Geography, 11(3): $529-557$

Modrego, F., \& Foster, W.E. (2021). Labor productivity response of the micro-and-small-firm sector to business entries and exits. Journal of Small Business Management. https://doi.org/10.1080/0 0472778.2021 .1934852

Modrego, F., McCann, P., Foster, W.E., \& Olfert, M.R. (2014). Regional market potential and the number and size of firms: Observations and evidence from Chile. Spatial Economic Analysis, 9(3), 327-348.

Modrego, F., McCann, P., Foster, W.E., \& Olfert, M.R. (2015). Regional entrepreneurship and innovation in Chile: a knowledge matching approach. Small Business Economics, 44, 685-703.

Modrego, F., McCann, P., Foster, W.E., \& Olfert, M.R. (2017a). Location and Entrepreneurship: Insights from a Spatially-Explicit Occupational Choice Model with an Application to Chile.
Journal of Regional Science, 57(4), 669-697.

Modrego, F., Paredes, D., \& Romaní, G. (2017b). Individual and place-based drivers of self-employment in Chile. Small Business Economics, 49(2), 469-492.

Naudé, W. (2010). Entrepreneurship, developing countries, and development economics: new approaches and insights. Small Business Economics, 34(1), 1-12.

Nickell, S. (1996). Competition and corporate performance. Journal of Political Economy, 104, 724-746.

OECD. (2004). Promoting entrepreneurship and innovative SMEs in a global economy: Towards a more responsible and inclusive globalisation. Second OECD conference of ministers responsible for small and medium-sized enterprises (SMEs), Istanbul, June 2004.

OECD (2012). Promoting growth in all regions. OECD Publishing, Paris, https://doi. org/10.1787/9789264174634-en.

Oyarzo, M., Romaní, G., Atienza, M., \& Lufín, M. (2020). Spatio-temporal dynamics in municipal rates of business start-ups in Chile. Entrepreneurship and Regional Development. https://doi. org/10.1080/08985626.2020.1743769

Parker, S.C. (2005). Explaining regional variations in entrepreneurship as multiple occupational equilibria. Journal of Regional Science, 45(4), 829-850.

Parker, S.C. (2009). The economics of entrepreneurship. Cambridge University Press.

Parker, S.C. (2013). Do serial entrepreneurs run successively better-performing businesses? Journal of Business Venturing, 28(5), 652-666.

Puga, D. (2002). European regional policies in light of recent location theories. Journal of Economic Geography, 2(4), 373-406.

Pezzi, M.G., \& Modrego, F. (2020). Beyond entrepreneurial culture in the entrepreneurial ecosystems framework: Contributions from economic anthropology. In Tsvetkova, A., Schmutzler, J., Pugh, R. (Eds.), Entrepreneurial Ecosystems meet Innovation Systems. Edward Elgar.

Rappaport, J. (2007). Moving to nice weather. Regional Science and Urban Economics, 37(3), 375-398. 
Reynolds, P., Bosma, N., Autio, E., Hunt, S., De Bono, N., Servais, I., \& Chin, N. (2005). Global entrepreneurship monitor: Data collection design and implementation 1998-2003. Small Business Economics, 24(3), 205-231.

Rosenthal, S.S., \& Strange, W.C. (2004). Evidence on the nature and sources of agglomeration economies. In J. V. Henderson \& J.-F. Thisse (Eds.), Handbook of Regional and Urban Economics: Cities and Geography, Vol. 4 (pp. 2119-2171). North Holland.

Roundy, P.T., Bradshaw, M., \& Brockman, B.K. (2018). The emergence of entrepreneurial ecosystems: A complex adaptive systems approach. Journal of Business Research, 86, 1-10.

Sato, Y., Tabuchi, T., \& Yamamoto, K. (2012). Market size and entrepreneurship. Journal of Economic Geography, 12(6), 1139-1166.

Schoar, A. (2009). The divide between subsistence and transformational entrepreneurship. In J. Lerner \& S. Stern (Eds.), Innovation Policy and the Economy, (pp. 57-81). National Bureau of Economic Research. https://www.journals.uchicago. edu/doi/10.1086/605853

Schumpeter, J.A. (1934). The theory of economic development, Cambridge, MA: Harvard University Press.

Schumpeter, J.A. (1942). Capitalism, socialism and democracy. Harper and Brothers.

Shane, S. (2009). Why encouraging more people to become entrepreneurs is bad public policy. Small Business Economics, 33,141-149.

Stam, E. (2015). Entrepreneurial ecosystems and regional policy: a sympathetic critique. European Planning Studies, 23(9), 1759-1769.

Stam, E., Audretsch, D., \& Meijaard, J. (2008). Renascent entrepreneurship. Journal of Evolutionary Economics, 18(3-4), 493.
Stephens, H.M., Partridge, M.D., \& Faggian, A. (2013). Innovation, entrepreneurship and growth in lagging regions. Journal of Regional Science, 53(5), 778-812.

Szerb, L., Acs, Z., Autio, E., Ortega-Argiles, R., \& Komlosi, E. (2013). REDI: The regional entrepreneurship and development index: Measuring regional entrepreneurship. Final report. European Commission, Directorate-General for Regional and Urban policy. REGIO DG.

Tamvada, J. P. (2010). Entrepreneurship and welfare. Small Business Economics, 34(1), 65-79.

van Praag, C.M., \& Versloot, P.H. (2007). What is the value of entrepreneurship? A review of recent research. Small Business Economics, 29(4), 351-382.

Welter, F., Baker, T., Audretsch, D.B., \& Gartner W. (2016). Everyday Entrepreneurship - A Call for Entrepreneurship Research to Embrace Entrepreneurial Diversity. Entrepreneurship Theory and Practice, 41(3), 311-321.

Wennekers, S., \& Thurik, R. (1999). Linking entrepreneurship and economic growth. Small Business Economics, 13(1), 27-56.

Wennekers, S., Van Stel, A., Thurik, R., \& Reynolds, P. (2005). Nascent entrepreneurship and the level of economic development. Small Business Economics, 24(3), 293-309.

Williams, N., \& Vorley, T. (2014). Economic resilience and entrepreneurship: lessons from the Sheffield City Region. Entrepreneurship \& Regional Development, 26(3-4), 257-281.

World Bank. (2016). Growth entrepreneurship in developing countries: A preliminary literature review. The World Bank. 